\title{
War, anxiety, optimism and triumph: a study on science in the main Brazilian TV news
}

\author{
Yurj Castelfranchi, Luisa Massarani and Marina Ramalho
}

\begin{abstract}
We analysed the representations of science and of scientists at Jornal Nacional, the main Brazilian TV news. We carried out content and frames analysis, besides the lexical and semantic analysis of the transcriptions of the science and technology stories. Our results show a narrative that highlights the novelties and the epopee of the scientific advance, mainly in the health field. But to the emotional palette feelings of combat, anxiety and triumph were added. The face of the scientist presented by the TV news is mainly masculine, suggesting a stereotyped role of the male and female scientist: meanwhile men go out to literally explore other worlds, women take care of health and of the body.
\end{abstract}

KEYWORDS: Images and representations of science and technology, Science and media

\section{Introduction}

Television is the most widespread mass communication in Brazil and it is present in $96.9 \%$ of 59.4 million Brazilian homes according to the latest National Survey by Household Sampling carried out in 2011 by the Brazilian Institute of Geography and Statistics. Besides entertainment, television is used as an important source of information in general and to inform about science and technology. The most recent national survey about the public perception of science and technology conducted in 2010 by the Ministry of Science, Technology and Innovation and by the Life Museum showed that $71 \%$ of 2016 people interviewed declared that they watch TV programmes on Science and Technology [1]. This mass communication ranked first, being the most frequently chosen source of information. The newspaper ranked second, obtaining $51 \%$ of the answers, and the third place was magazines (43\%).

A similar trend can be observed in other Latin American countries. According to a survey carried out in 2004 by the Colombian Institute of Development, Science and Technology 'Francisco José Caldas', 76\% of the people interviewed declared that they get information about science and technology on television [2]. A research carried out in five Latin American cities (Bogotá, Buenos Aires, Caracas, Santiago de Chile and São Paulo) and presented in 2008 showed that a considerable number of respondents - ranging from $60 \%$ in Caracas to $80 \%$ in the other cities - reported that they watch documentaries about 
science, technology and nature on television. ${ }^{1}$ In Brazil, the national survey mentioned earlier found that $65 \%$ of the respondents declared that they are interested in topics related to science and technology or that there is a demand for scientific content by the Brazilian population.

In this context, television serves as an important mediator in the way the Brazilian population understands and acquires information about science. This finding is even more important in a country where education presents shortcomings, as in the case of Brazil. For a significant portion of the population that has already completed, or abandoned, formal education, television is the main connection with the scientific world. However, most studies aimed at understanding the coverage of science focus more on the contexts of the United States and Europe [3-5], especially in the printed media [6-10].

Ramalho et al. [11] showed that the Brazilian TV news that has the highest audience during prime time, Jornal Nacional (JN), produced by the broadcaster Globo, considers science and technology (S\&T) as some of the most important areas of attention. Although it does not have a specific section for S\&T, nor does it have science journalists within its team, $7.3 \%$ of its coverage is dedicated to this area. This shows how important the analysis of $J N$ is - the object of study of this paper - considering that it is an important source of information about $\mathrm{S} \& \mathrm{~T}$ that reaches millions of people every day.

However, there is a significant gap in the studies carried out on S\&T content conveyed by this TV programme, despite its importance. While we were searching the database of the theses and dissertations of Capes - a body of the Ministry of Education that collects the whole Brazilian production - we identified only 15 works on $J N$, with four dealing with the science coverage. Oliveira [12] analysed three reports of science communication; Andrade [13] examined 124 editions of the programme, corresponding to approximately four months of broadcasting; Ramos [14] and Alberguini [15] dealt with two months of science coverage by this programme. These studies have a rather confined purpose as compared to the present work, which is presented in detail in the following sections.

\section{Methodology}

Our study focussed on the TV construction of representations and stories about the functioning and the role of S\&T within society, as well as on the role of scientist. We set up analysis tools to visualise not only those aspects of science journalism that are most extensively studied and that rely on facts (the importance attributed to S\&T in a specific mass media, the emphasis in international or national research; the use of sources, etc.), but also the narrative processes and emotional frames used. Besides providing a first, general description of the characteristics of an empirical corpus barely explored in Brazil (topics of science journalism on television programmes with high audience), our objective was to address specific questions about the construction and placement of a technical-scientific narrative. What type of adjectives and emotions are used when the theme is scientific or

\footnotetext{
${ }^{1}$ The results were presented at the Ibero-American Congress Citizenship and Public Policies on S\&T held in Madrid in 2008.
} 
technological? What type of narrative frames are present and associated with what type of images and symbols? Our hypotheses were based on the fact that such narrative elements and emotional connotations are important in order to understand both the functioning of S\&T communication and the way it is understood by the audience. Our hypotheses were also based on the fact that the presence of narrative elements, such as risks or benefits, controversies or innovation, or ethical or political aspects, is adjusted in a different way when different aspects of S\&T are addressed, or when different stakeholders are involved. We, therefore, aimed to provide information about specific associations with the weight and placement of the topics within the structure of the programme and the images or emotions utilised for different topics and stakeholders involved. In addition, we analysed the characteristics of the presence of female scientists in the field and the gender differences related to different narrative contexts.

The specific corpus of this study was the coverage of science and technology by the TV news Jornal Nacional (JN), broadcast by Rede Globo. ${ }^{2}$ Besides having the highest audience ratings among Brazilian TV news available on terrestrial television, in April 2013 it registered an average of $31 \%$ of audience and 54\% of share (i.e. the percentage of people who are watching the television at a given time as compared to all the TV sets that are switched on during that time) [16], $J N$ also reaches the largest number of people in the country since it reaches all areas in Brazil where there is electricity, and is also the longest-lasting one, being transmitted without interruption since 1969. According to its chief-editor and journalist, William Bonner, "Jornal Nacional aims to show the most important events that happened in Brazil and in the world on that day in an unbiased, pluralistic, clear and correct way" [17].

We analysed 12 months (between April 2009 and March 2010). The sample was obtained using the constructed week methodology $[18,19]$ through which the amount of information to be analysed is considerably decreased, allowing every day of the week to have the same likelihood of being represented in the sample, but the statistic validity of the sample is guaranteed. In our analysis we considered a constructed week by month (from Monday to Saturday): the sample amounts to 12 constructed weeks during the period of a year, which means 72 episodes of $J N$. This sample is statistically representative of the programming of the whole year observed. For example, the identified percentages that were related to the presence of female scientists, as well as for the other variables measured, would very likely remain the same, if we had analysed the production of the whole year.

Each programme was seen in full, aiming to select scientific topics. In order to define what topics should be included in the sample, the researchers of the Ibero-American Network for Monitoring and Training in Science Journalism created a protocol based on what proposed by Rondelli [20] (for more information about the protocol, please refer to

\footnotetext{
${ }^{2}$ This study was supported by the National Council for Scientific and Technological Development and the Foundation for Research Support of the State of Rio de Janeiro. It is also associated with the IberoAmerican Network for Monitoring and Training in Science Journalism, which was created in 2009 after a call by the Ibero-American Programme for Science, Technology and Development (CYTED) made of institutions from ten countries in the region. Information available on: www.museudavida.fiocruz.br/redejc.
} 
Massarani and Ramalho [21]). In order to be classified as scientific story and be included in the sample, the news unit should meet at least one of the following requirements: explicitly mention a scientist, researcher, university professor or a an expert in general (provided that they were linked to a scientific institution and commented on issues related to science); mention research institutes or universities; mention scientific data or research findings; mention scientific policy; deal with science communication. Although the last two criteria may lead to include topics that do not necessarily link directly to any research, discovery or investigation, they were included because, on the one hand, the debates on science and technology policy and dissemination of scientific knowledge are an integral part of the construction of the debate on science and technology, on their role in society, on their dissemination and appropriation by society. They are, therefore, key elements to understand the media representations of S\&T. On the other hand, they include symbolic elements that are essential to understand the discourse and the framings where S\&T are narrated and placed.

The stories that were collected - a total of 77 - were analysed through a triangulation that considered both quantitative and qualitative techniques. With reference to the quantitative analysis, all the stories were codified by at least two codifiers and were estimated through Krippendorf's alpha coefficient (inter-coder reliability). We improved the definitions of the categories which turned out to be ambiguous due to the high rates of conflict between codifiers or we removed them to achieve a protocol where the inter-coder reliability was satisfactory for the most complex variables, and good or excellent for the simplest variables (alpha $>0.8$ ). First, we carried out a content analysis based on a protocol that was developed in the context of the Ibero-American Network for the Monitoring and Training in Science Journalism [21], which, besides the classic content analysis variables and categories, includes a part of codification of the frames. Similarly, the definition of the frames followed the protocol developed by this Network, having as a starting point the model proposed by Nisbet, Brossard and Kroepsch [22]. Each story may be classified up to three different frames: new research, new technological development, scientific background, the impact of science and technology in society, ethics and morality, political strategy / public policies and regulation, scientific controversy, scientific uncertainty, personalisation and cultural dimension of science (please see table 1 for further details): ${ }^{3}$

Along with content analysis, ${ }^{4}$ we analysed the transcription of the stories that are made available online to the public by $J N$. We conducted a semantic and lexical analysis of scientific stories, using the QDA Miner software by Provalis Research, which supports quantitative (content and text), mixed-model and qualitative analysis (Computer Aided Qualitative Data AnalysiS - CAQDAS) [23].

In particular, we used the semantic categorisation of the software, on the one hand, to identify emotional aspects associated with the narrative of S\&T, but on the other hand we used two methods to group both the most frequent words in the texts and the content analysis variables we had identified: the hierarchical clustering and the multi-dimensional

\footnotetext{
${ }^{3}$ For more details about this study, see: [21].

${ }^{4}$ For more information about the content analaysis carried out in this study, see: [11].
} 
Table 1. Description of the frames.

\begin{tabular}{|l|l|}
\hline Frames & Description \\
\hline New research & $\begin{array}{l}\text { Focus on new research dissemination, announcement of new discov- } \\
\text { eries or application of new scientific knowledge, new remedies or } \\
\text { treatments, results of clinical research }\end{array}$ \\
\hline $\begin{array}{l}\text { New technological } \\
\text { development }\end{array}$ & $\begin{array}{l}\text { Focus on new experimental developments, technical processes or } \\
\text { new technologies, including both those strictly linked to its use in } \\
\text { the field of scientific research and those for different markets (for } \\
\text { example, new mobile phone devices, a new type of fuel, etc.). }\end{array}$ \\
\hline Scientific background & $\begin{array}{l}\text { General scientific antecedents of the issue (for example, the descrip- } \\
\text { tion of research works) General scientific antecedents of the issue } \\
\text { (for example, the description of previous research, summary of re- } \\
\text { sults and conclusions that are already known). }\end{array}$ \\
\hline Impact of S\&T & $\begin{array}{l}\text { It presents situations whereby science or research have a direct (pos- } \\
\text { itive or negative) impact on society, for example accidents in nuclear } \\
\text { stations, shortage of energy, biosafety, improved life conditions and } \\
\text { environmental recovery, controversial issues and risks in the applica- } \\
\text { tion of S\&T. }\end{array}$ \\
\hline Ethics / Morality & $\begin{array}{l}\text { Focus on research ethics or morality, announcement of a special re- } \\
\text { port about ethics, prominence attributed to religious or value per- } \\
\text { spectives, emphasis on bioethics, debate on whether to hinder scien- } \\
\text { tific progress debate on the nature of human life }\end{array}$ \\
\hline $\begin{array}{l}\text { Political Strategy / } \\
\text { Public Policies / }\end{array}$ & $\begin{array}{l}\text { Focus on political strategies, actions or deliberations made by politi- } \\
\text { cians, presidential administrations, of members of Congress, of other } \\
\text { bodies of the federal or state system, government agencies, and pres- } \\
\text { sure by lobby groups }\end{array}$ \\
\hline $\begin{array}{l}\text { Market / } \\
\text { Proponts / }\end{array}$ & $\begin{array}{l}\text { Focus on the stock prices, the growth in a certain industry or com- } \\
\text { pany that is related to scientific investigation or its product, investors' } \\
\text { reaction, its product development for the market, its national econ- } \\
\text { omy implications, global competitiveness. }\end{array}$ \\
\hline
\end{tabular}

scaling. These methods allow one to identify what elements tend to occur jointly in the same story, or in the same paragraph of a story. The algorithm of multidimensional scaling calculates the proximity of words or codes that occur in the analysed stories and allows one to view the result in the form of a conceptual map. Each point of the map represents an item (a word or an analysis code) and the closeness between the items represents the probability for them to occur together in the same story, paragraph or sentence. The hierarchical clustering allows one to complete this information through and algorithm that, instead of focussing on the distance of a word to the others, identifies whole clusters of words or codes which tend to occur together. 


\section{Results and discussion}

\subsection{Novelty and progress: the narrative of $S \& T$ optimism}

Thanks to the stories categorisation based on narrative frames, our protocol of content analysis allowed us to identify some aspects of the construction of the journalistic discourse and the style used. The finding points to a narrative that seems to highlight, within the S\&T discourse, the aspects related to progress novelty and epopee. A considerable amount of stories that are focussed on the scientific and technological novelty and on the social impact of the progress are predominantly described as positive. These are well known aspects which we also discussed using more vast historic documents [24].

The analysed stories most frequently focussed on: "new research" (57\% of the texts analysed), "impact of S\&T" (26\% of the stories) and "scientific background" (25\%). Less than $20 \%$ of the stories focussed on the remaining elements. Besides novelty, the S\&T discourse on $J N$ seems to be linked to progress and the impact of S\&T, a generally positive and optimistic narrative. In total, $30 \%$ of the stories mention some tangible benefit of S\&T and $25 \%$ report some promise (i.e. a potential or future benefit). Only $8 \%$ of the stories mention some tangible disadvantage and just $6 \%$ explicitly report potential risks or disadvantage. Two thirds $(66 \%)$ of the stories present the news within some context. However, a central aspect of the context and of the functioning of science, a critical discussion and a sceptical view of the hypothesis, results and theories, which are fundamental in the construction of scientific knowledge, are hardly present. Only six stories (8\% of the total) mention the existence of some controversy, and all the controversies mentioned refer to medicine or environment. The collision between different researchers, different interpretations or models - frequent in all scientific fields - is therefore hardly visible.

One of the categories in our analysis protocol allows one to identify if the reports include recommendations aimed at the audiences (for example, how to decrease the risk of contracting the flu, healthy food, etc.). We observed recommendations in 19\% of S\&T stories. As expected, the only areas of knowledge where there is a significant amount of recommendations were that of medicine and health (29\% of the stories with this topic included some type of recommendation) and biology (22\%). Less predictable was the finding that there is a significant association between the existence of recommendations and the location of the subject in the TV news: $80 \%$ of stories containing recommendations to the viewer are present in the first part of the $J N$, where the stories that are considered as the most important are inserted by the newscast. In contrast, only $34 \%$ of the stories that do not contain recommendations belong to the same block (which may indicate the editorial choice to give some attention to such matters; chi-squared test, $\mathrm{p}<0.01$ ). Another factor that seems to affect the importance of the news (and its placement in the $J N$ ) is the existence of social, political, technical or scientific controversies. Eight percent of the S\&T stories included such controversies, $87 \%$ of which are announced at the opening of $J N$, as opposed to $42 \%$ of the stories that do not present controversies. 
Obviously, the duration of the stories tends to be considerably longer when the news report presents interviews with scientists, when the piece of news is conceptualised or the stories focus on scientific antecedents of a theory, discovery or invention. ${ }^{5}$

In our view, it seems to be an interesting finding that in our sample the focus on "scientific background" tends to be separated from the focus on "new research". This may indicate that there is a certain stylistic aspect in S\&T journalism during $J N$. In other words, when a new report focuses on an investigation, the story hardly dedicates a considerable amount of time to antecedents. Only $7 \%$ of the news reports whose narrative is based on the novelty of a research also focuses on scientific background, as opposed to $48 \%$ of the remaining stories (i.e. those that do not focus on "new research" (significant chisquared test, with $\mathrm{p}<0.001$; all the following probabilities refer to the significance of the chi-squared test for the crossing between two qualitative variables). We interpreted these findings as a confirmation of our hypothesis based on an aesthetics and narrative structure in the analysed stories that enlighten S\&T mainly through images of novelty, marvel, news that, like pearls or bright flames, build the bricks in the narrative, epic, progress. The process of production and questioning of knowledge is less emphasised: previous theories were discarded, old ideas are now restored in the light of new findings and discussions, and the explanation of historical and social aspects of scientific and technical progress. When the focus is on the novelty of the research, the narrative tends to "forget" that innovation comes from the past, arising from a context and not just from a sudden enlightenment. In short, the "novelty" - the central criterion of newsworthiness in journalism in general, and with even greater emphasis in science journalism [25] -, seems to play a predominant role in the story with regards to the science coverage by $J N$.

The use of visual aids is also a signal of the aesthetics and narrative produced by $J N$. First, animations are more frequent in content whose narrative revolves around new technological developments. In total, $67 \%$ of the stories that focus on new technological development include animations, as opposed to $23 \%$ of others (significant with $\mathrm{p}<0.01$ ). In addition, $47 \%$ of the stories that mention potential benefits of S\&T include animations, as opposed to $22 \%$ of the others $(\mathrm{p}<0.05)$.

Among the stories lasting longer than $1 \mathrm{~m} 50$ s, more than $90 \%$ include a context, against $29 \%$ of the others with shorter duration (the average duration of the selected stories was $2 \mathrm{~m} 09 \mathrm{~s}$, with $1 \mathrm{~m} 31 \mathrm{~s}$ of standard deviation, with the shortest story lasting $15 \mathrm{~s}$ and the longest one lasting $7 \mathrm{~m} 40 \mathrm{~s}$ ). As expected, the time that can be dedicated to a news report is a determining factor for the journalist to be able to deepen the topic including a detailed contextualisation. However, it is worth highlighting that editors of $J N$ seem to regularly pay attention to the contextualisation of the news, as also in stories lasting less than 2 minutes a context occurs rather frequently.

\footnotetext{
${ }^{5}$ The texts including the presence of scientists last on average 3minutes 1 second, against 1 minute 16 seconds for texts without scientists. The texts that include a contextualisation have an average duration of 2 minutes 41 seconds, against 1 minute 7 seconds for the others. The texts that contextualise the news about science last 3 minutes 24 seconds on average, against 1 minute 44 seconds for the others.
} 


\section{CANCER WATER RESEARCHERS HEALTH RESEARCHSTUDY SCIENTISTS UNIVERSITY ${ }_{\text {TEST }}$ LIFE WOMEN INSTITUTE $_{\text {FLU WORLD DIESEASE RISK PLANET }}$ DOCTORS VACCINE EDUCATION CELLL TREATMENT RESULT EARTH DOCTOR MEDIA PROFESSOR PATIENTS VIRUS CONSUMPTION INTERNET NASA SCIENCE USP* MaMmogRAPHY RESEARCH ENERGY MOON ROBOTS COMPUTER CAUSE LABORATORY KIDS SOLUTION BODY AMERICAN DISCOVERY TECHNOLOGY HUMANS FAT PAIN STUDY CHALLENGE AMERICANS EXPERTS AGENCY EFFECT BLOOD TEMPERATURE PATIENT SPATIAL MEDICINE WOMB sYNPTOMS вовот WOMAN THEY DISCOVERED HUMAN HOSPITAL ENVIRONMENT TRANSPORT \\ * UNIVERSITY OF SÃO PAULO}

Figure 1. Words that were used more in the analysed stories, in descending order. Pronouns, adverbs, articles and common nouns of the Portuguese language were removed from the list, leaving only the words associated with S\&T. The order in which these words are displayed refers to the number of times they were used, whereas the size refers to the number of stories in which each word was used. For example, "cancer", "water" and "researchers" (the first ones in the list) are the most repeated words (they were used 51, 46 and 44 times respectively). "Researchers", "research" and "university" (bigger size) occurred in the largest number of stories (in 31, 27 and 27 stories respectively).

\subsection{War, anxiety, triumph: the emotional nuances of the techno-scientific discourse}

The content analysis of transcriptions using the QDA Miner software gave interesting results. Again, it is possible to notice how much emphasis was given to health. Among the most frequently used words that are associated with S\&T in the analysed stories, some have a major emphasis: "cancer", "health", "test", "life", "flu", "disease", "doctors", "vaccine", "cells", "treatment", "doctor", "patients", etc. (figure 1). "Health" is also a word that, besides being used several times, is among those that occur in the largest number of different stories (25\% of the stories).

Through the QDA Miner software one can also analyse the occurrence of terms with semantic connotations of emotional type. This is done on the basis of the categorisation of the Portuguese dictionary based on psychological and cognitive features [26], which allows one to group and work on groups of words or expressions as if they belonged to the same analysis category (in our case, basic emotions such as anxiety, sadness, love, aggression, etc.; see figure 2).

The emotional connotations that are most frequently used in the science coverage by $J N$ are associated with the categories of "aggression" and "anxiety". Terms that belong to the semantic field of war, aggression, competition or fight are particularly frequent. This is due to different factors. On the one hand, the scientific discourse, as for the political 


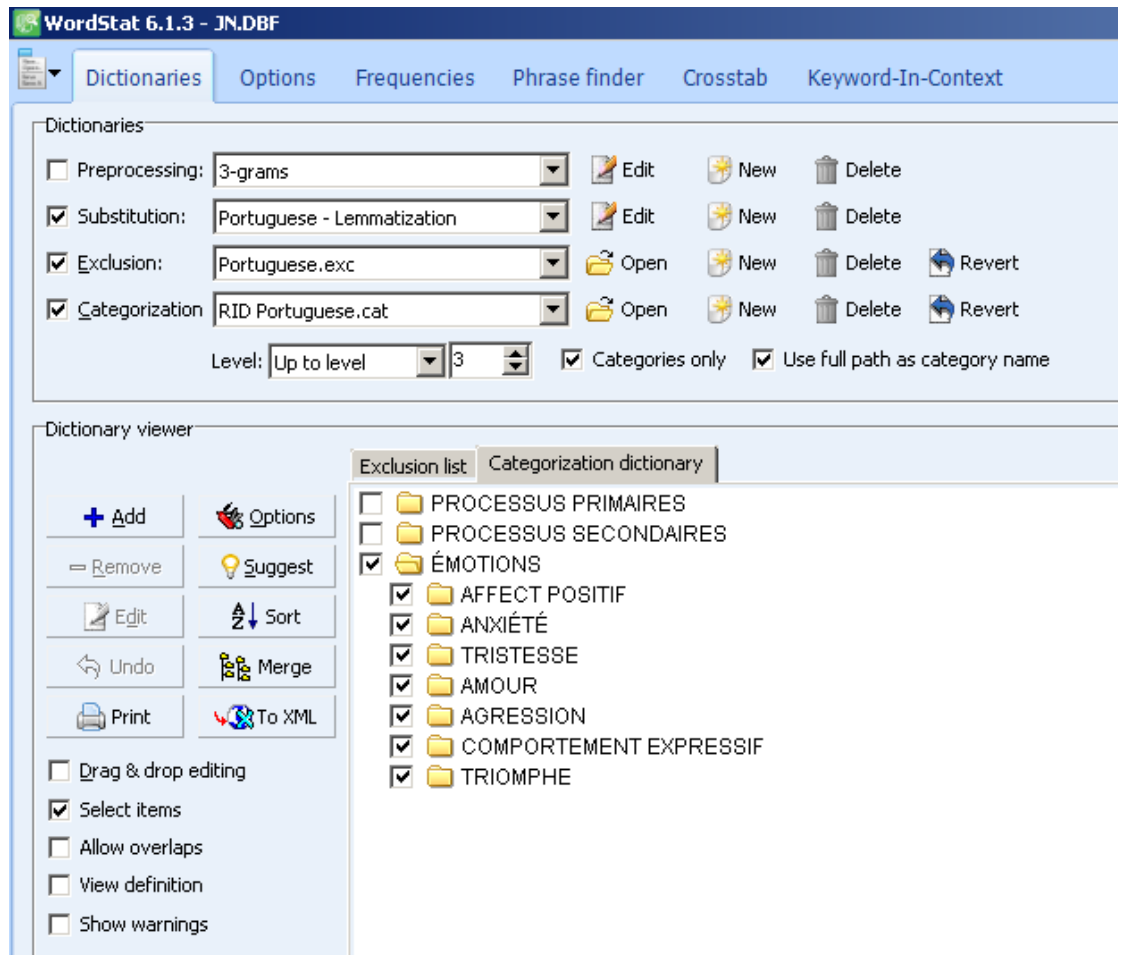

Figure 2. Categorisation of words and expressions used in the news reports by $J N$ that are based on emotions. Source: WordStat 6 package for QDA Miner.

discourse (both largely present in the stories about S\&T), often use military, sport or competition metaphors: "the fight against" diseases; there are "wars" against cancer that need to be "won"; bacteria must be "attacked" or "invade" our body, etc. The results are illustrated below with some examples:

[Case \#16]

Instead of growing the virus in eggs like in the traditional process, the laboratory has succeeded in the cell growth. The active influenza viruses are put in contact with the healthy cells. They invade the cell nucleus and multiply, to spread the infection.

[Case \#30]

Scientists and environment experts from all over the world are discussing ideas to fight against global warming.

[Case \#44]

The battle of scientists is to prevent the dengue mosquito from becoming resistant to the 5 types of poison used to fight against it.

[Case \#60]

... The coin-sized disk attracts immune system cells. After being activated by proteins, the cells organise themselves and get ready to learn to attack the cancer. 
... The proteins attracted these cells, which were activated by chemical signals, and started to counter-attack the enemy: the cancer cells.

[Case \#66]

They created a nanoparticle, a molecule able to identify the cells that threaten to block the arteries.

[Case \#74]

The American first lady, Michelle Obama, engaged in the fight against childhood obesity.

Secondly, a considerable amount of stories deals with environmental topics, frequently using terms such as "degradation", "destruction" etc.:

[Case \#30]

A battallion of friends against the degradation of an environmental park in the metropolitan region of Belo Horizonte. They planted the seedlings. And now, during the drought, they bring water from far away to water the future forest.

[Case \#85]

At this point, the destruction of the forest has reached an irreversible cycle, the research lead, Richard Betts, has stated.

In addition, the scientific debate is marked by a critical - and self-critical - ethos of distrust, caution, checking, testing and refutation of the hypothesis, which Robert K. Merton [27], ${ }^{6}$ while identifying the ethos of science, named "organised scepticism". This is visible in stories that deal with scientific controversies or science methods and processes:

[Case \#54]

William: Doctor, the president of the Brazilian Society of Breast Unit, Dr. Ricardo Chagas, raised some critical observations regarding these recommendations which, let's say, have been reinforced today in the US.

[Case \#84]

A mistake. Genetics is not the only cause of the disease. Indeed, $90 \%$ of cancer cases are related to other risk factors.

Science journalism pays attention to and emphasises aspects (also typical of the Hollywood iconography) of scientific research as a potential source of risks or dangers. The visual and verbal description of the laboratories frequently pays attention to protection and safety equipment (gloves, coats and masks, etc.), whose semantic connotation is present in the field of threat:

[Case \#5]

Dr. David Uip: There are two masks. The one we saw in the news report, a relatively protective, yet important, mask and a mask that we use in hospitals, which is a protective duck shape nozzle mask that is competent and long-lasting.

\footnotetext{
${ }^{6}$ For more details about Mertonian norms, see also [24].
} 
The cases in which the story deals with social and human sciences are mostly associated with news about social problems, especially those related to violence and crime. In these news reports the occurrence of terms such as "murder", "murdered", "invasion", etc. is frequent. The dimension of anxiety also occurs rather frequently. Reports and research works can bring "alarming", "worrying" results, etc.:

[Case \#18]

Beware the consumption of raw egg. Prefer well cooked eggs and store them in the fridge, as this is better for your health", reported Maria Cecília Britto, director of the Food Area at Anvisa.

[Case \#38]

Climate change made news in Jornal Nacional. "The planet earth is in danger", warned Bonner. "The average temperature is rising worldwide", reported Fátima.

[Case \#52]

The risk is becoming increasingly higher every day in the country where obesity is now a national concern.

An important part of the news about health is dedicated to epidemics (dengue, influenza, etc.), the fear they generate, chronic diseases (Parkinson, Alzheimer, diabetes) or diseases whose cure has not been found yet:

[Case \#5]

William Bonner: Doctor, there is a lot of frightened people. This often happens when a disease like this arises. People are worried, they think they will die if they catch this flu. Do you have a mortality rate, or a percentage of people who will die when they contract this disease?

[Case \#87]

Next Saturday (25) a national campaign for the flu vaccination will start, yet lots of people are scared of the vaccine.

In addition, many studies, either in the biomedical, social or technological context, refer to an epidemiological aspect of calculation of probabilities and risk factors. They are, therefore, described as terms associated with risk, fear, etc:

[Case \#53]

Seven years ago, this same group argued that the mammography needed to be done every year after the age of 40 . The argument that is used now is that this test can scare more than help, diagnosing cancers that do not need to be treated and would never cause death.

In the field of social sciences, economic matters are often linked to a crisis, unemployment, a rise in inflation, etc., while news reports about social or socio-environmental problems often highlight the dimension of hazard. 
Less frequent, though still relevant in the construction of the discourse about S\&T in the analysed texts, are the dimensions that refer to the emotional connotations of "triumph". If S\&T are often associated with battles and fights, concerns and dangers, they are also reported as representing the necessary force to succeed. Metaphors of victory are, therefore, frequent in the texts analysed, even more than in the sample that covered the period of the anniversary of the landing of the man on the moon, a fact that was reported with epic tones:

[Case \#25]

40 years ago, millions of people followed the outcome of one of the greatest adventures in humankind: leaving the planet Earth.

[Case \#26]

The mark left in the region called "Sea of ??Tranquility" was the result of one of the greatest adventures of the human being. [...] The reporter Hilton Gomes, from TV Globo, was at Cape Canaveral, Florida, to cover the historic achievement. On July 16, 1969, the Saturn 5 rocket carrying the Apollo 11 spacecraft was launched. [...] But nothing has been as dramatic or had such an extraordinary success as that flight in July 1969 . "It's one small step for a man, one giant leap for mankind." [...] If the rocket of the module fails, Armstrong and Aldrin would be trapped in the lunar soil, with no chance of rescue. The rocket worked and the astronauts returned as heroes.

[Case \#38]

Meteorologist Viviane always dreamed of being an astronaut, so in 2006 she was excited: "It was a source of pride for everyone to see a Brazilian going into space" she said.

[Case \#47]

The American Space Agency celebrated the success of the mission that bombarded the lunar soil. A rocket and a satellite crashed into the moon Friday morning. The image was sort of disappointing. But NASA scientists applauded the result.

A second type of analysis confirms our findings. The QDA Miner uses two methods [28] to identify and group words used in texts, or codes of content analysis which tend to be found together in the same unit of analysis (subject, paragraph or sentence). As mentioned in the methodology, these are the hierarchical clustering and multidimensional scaling. The two algorithms allow one to produce conceptual maps and tree graphs, which we used in the analyses below.

In the conceptual map, we represent each item (i.e. a word, or a code of analysis) with a bubble whose size is proportional to the number of times a word (or a category of analysis) is repeated in the analyzed corpus. The distance between the bubbles represents the probability that such items have to be together in the same content, paragraph or sentence: two items that appear near in the map, often occur together in the units analyzed. Furthermore, the algorithm of hierarchical clustering allows us to mark with the same 


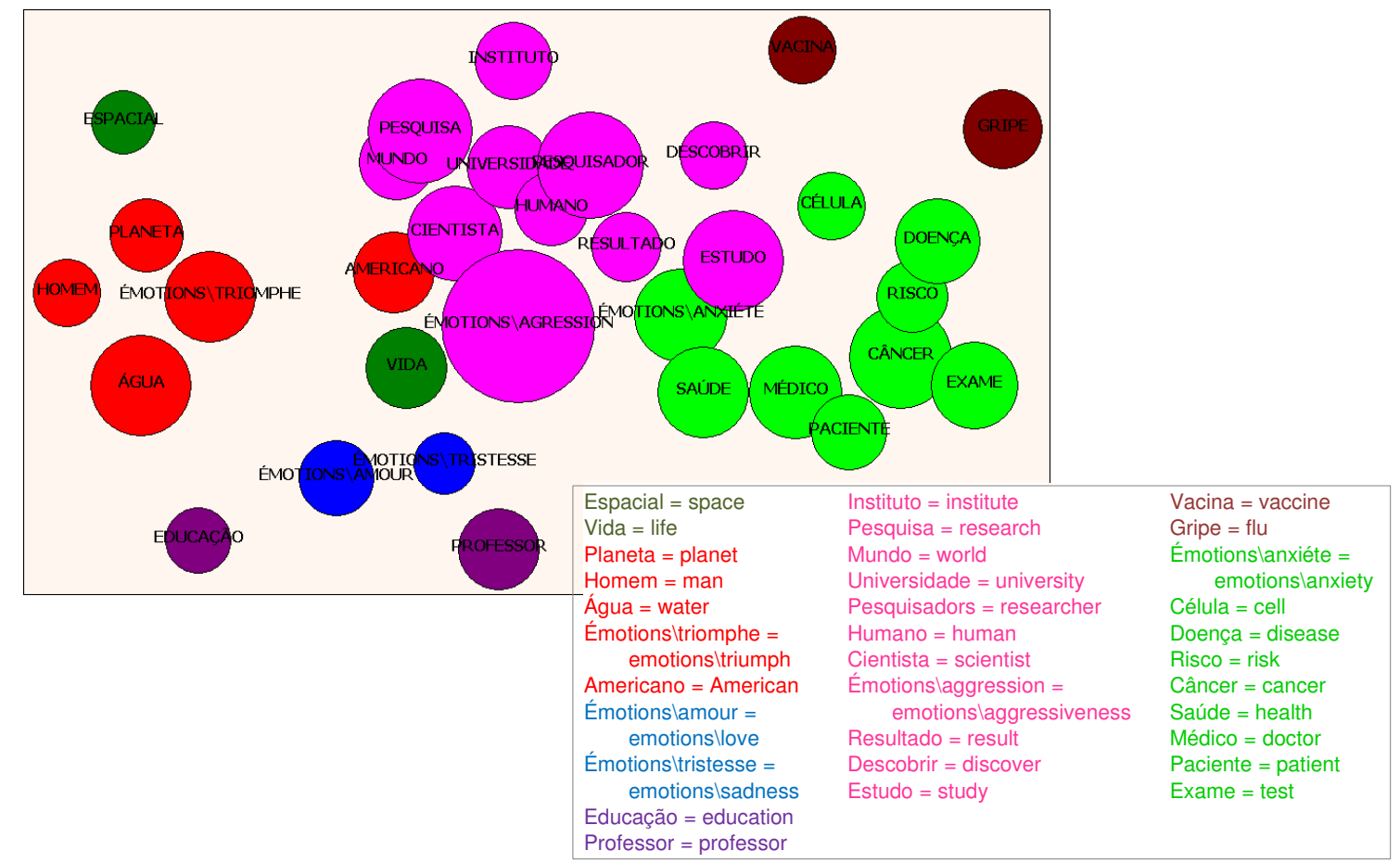

Figure 3. Conceptual map of the most used words and most frequent emotional connotations. The items that are not distant have more probability of appearing in the same paragraph of a text. The items in the same colour belong to a cluster of words or categories that tend to appear in the same paragraph (the graph shows only words and categories that were repeated at least 30 times in the whole corpus analysed).

color groups of words or codes that tend to appear together with higher frequency, as well as build a dendrogram that shows the hierarchical structure of such groups (such as the association between a group and other).

Based on these tools, we found that, on the one hand, in an entire text the emotions of anxiety, aggression and triumph are often associated with each other (have high proximity, i.e. high probability to occur together). On the other hand, when we analyzed the cooccurrence within a single paragraph, although aggression and anxiety continue to have good proximity (they are located at a short distance in the conceptual map), aggression is more frequently associated with the more common terms used in the reports of S\&T in general (research, researcher, university, etc.). Anxiety is often present in paragraphs that mention risks or, in general, are related to the semantic field of the body and health (belong to the same group as the words cell, flu, vaccine, etc.). The terms most associated with words connoting "triumph" are, as we also saw earlier, linked to aspects of achievement, progress, epic, typical of the discourse of the disclosure of science communication [24]. In our sample such terms turned out to be particularly frequent, due to the presence of texts about the anniversary of the first mission of man on the moon (figure 3 ).

We also applied the same type of analysis to the codes of our content analysis protocol, to see what frameworks, topics, or type of players tend to appear together in the same text. 


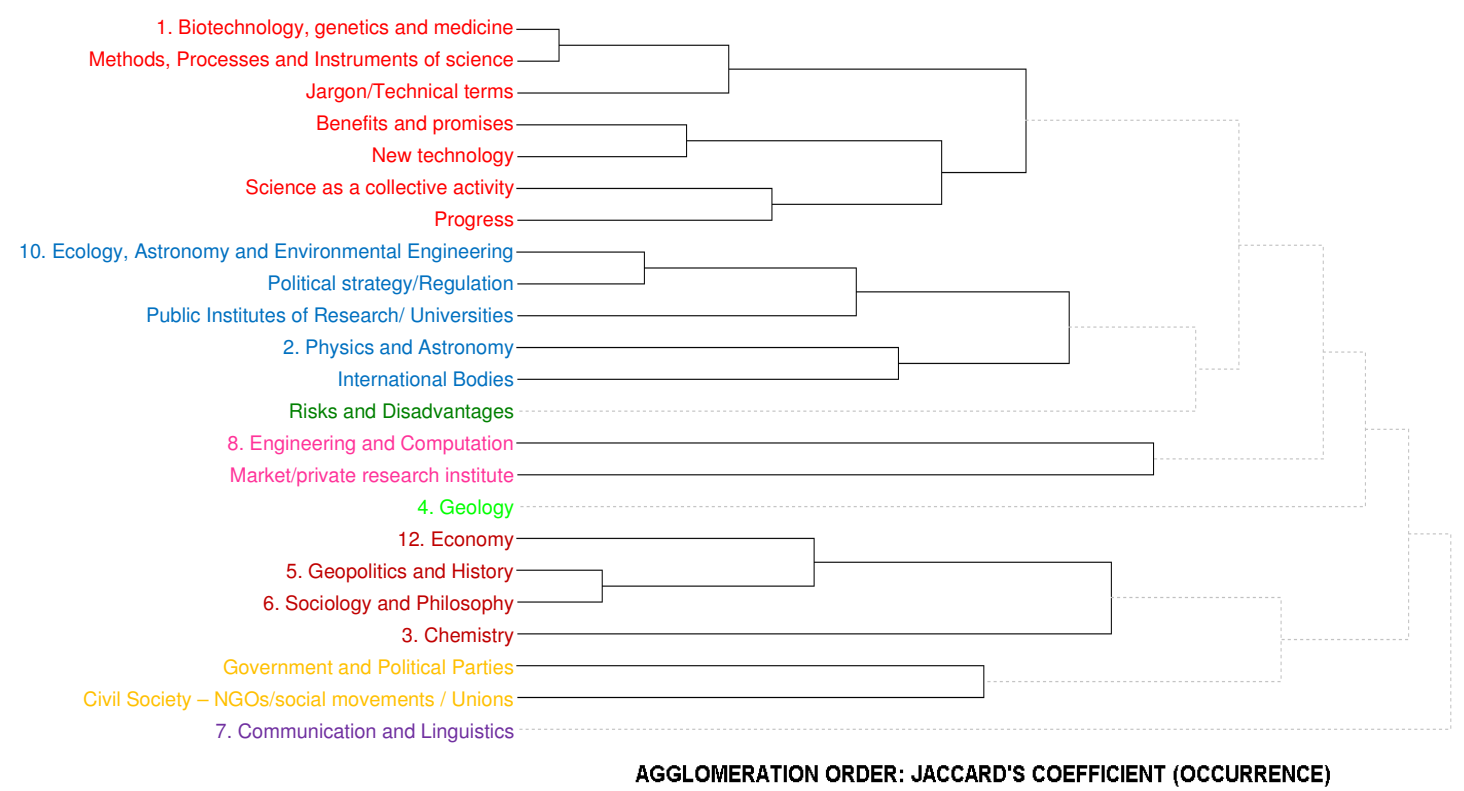

Figure 4. Tree graph (dendrogram) of the content analysis codes that most frequently occur in the same text.

On the basis on the hierarchical clustering analysis, some associations emerged between the analysis codes. The result of this type of analysis is presented in the form of a tree graph, or dendogram, whereby the vertical axis is made of the analysed codes, whereas the horizontal axis represents the clusters that appear to be more strongly linked. The degree of association is displayed from left to right: codes that are more strongly interconnected are linked closer to the left side of the graph. Figure 4 shows the results: biomedicine is the subject area that, in the texts of $J N$, is more frequently associated with the description of research "methods and processes" and to the "explication of technical terms". In turn, the focus on "new technologies" tends to be associated with the discussion about "promises and benefits", and more rarely to risks and dangers, thus confirming our hypothesis of a narrative that is optimistic and focussed on progress.

\subsection{The masculine face of science}

The analysis of the stories collected also highlights some differences in the way scientists are represented, from a gender perspective. Firstly, in the stories covered by JN, male scientists are interviewed more frequently than women. Indeed, $33 \%$ of the stories analysed include interviews with male scientists, against $20 \%$ of the stories where female scientists are interviewed. The transcriptions of the news reports were marked where a man or a female scientist are mentioned or make declarations. As a result, besides the fact that male scientists appear more often, the amount of time dedicated to them or to their declarations tends to be almost as twice as long as the time dedicated to women (see figure 5). 


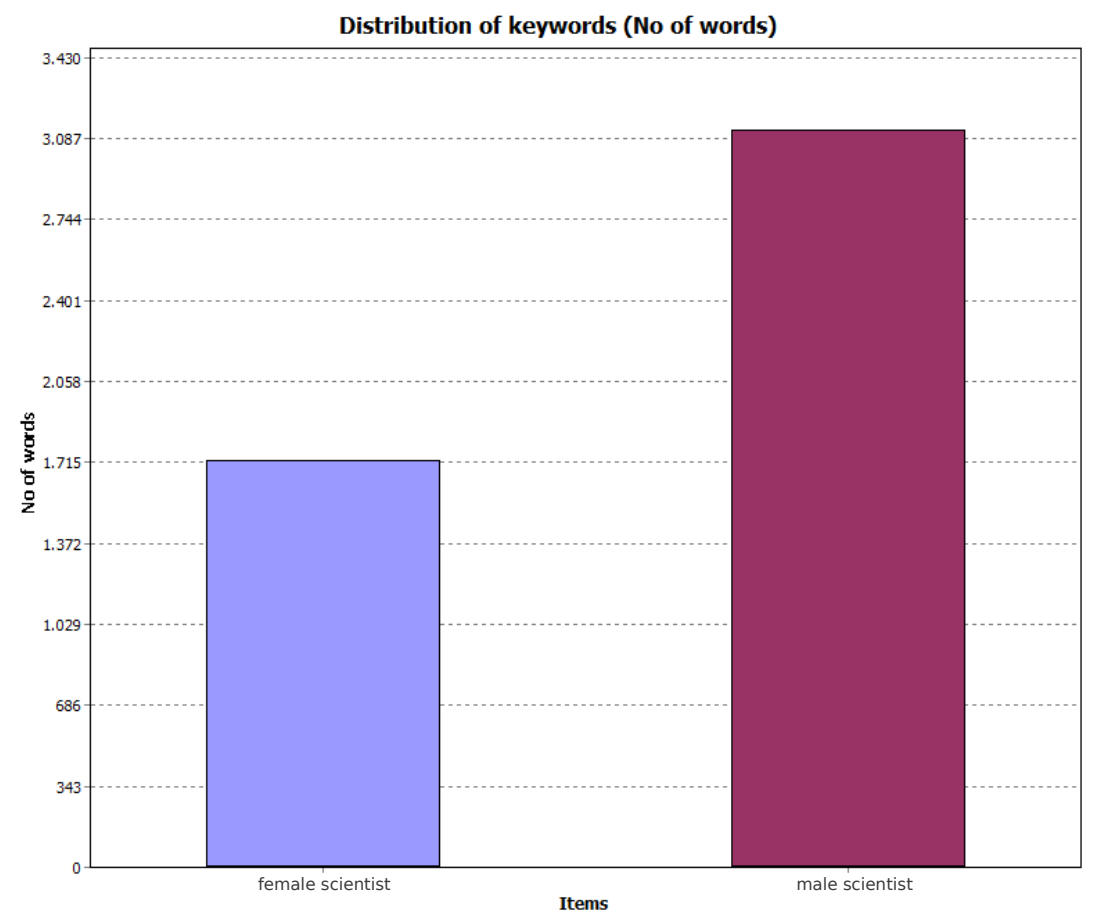

Figure 5. Total amount of words found in the stories collected from JN and used for sections where there is either a male or a female scientist.

In addition to this, when the scientist being interviewed is a foreigner, very often they are a man (95\% of the cases), whereas the percentage of women interviewed has increased to $32 \%$ if the scientist is Brazilian $(\mathrm{p}<0.005)$.

The narrative focus and the type of content also affect the probability of having a female scientist in the news report. When the narrative focus available in the news report is the story of a new research, there are fewer chances that the scientist interviewed is a woman: there are women in $11 \%$ of the stories with this focus, against $30 \%$ of the others $(\mathrm{p}<0.05)$. It is just a signal, which may be investigated with a larger corpus and through a discourse and image analysis. However, it might be related to the gender stereotype according to which creativity, ambition or bold and innovative attitudes are features more closely related to the semantic field of masculinity.

In addition to this, female scientists appear more often in the texts that mention the benefits of S\&T (35\%, against 13\% of the other). However, in our sample they were never interviewed in the selected stories that mention some kind of risk associated with S\&T. This is another signal which requires thorough investigation and may point to a hypothesis of a gender bias when the expert is asked to comment on S\&T implications, as it is well documented that in the literature of gender studies there are predominant social perceptions considering men's mind as more tangible, objective and critical and women's mind as the pole of corporeality, emotion and subjectivity. 


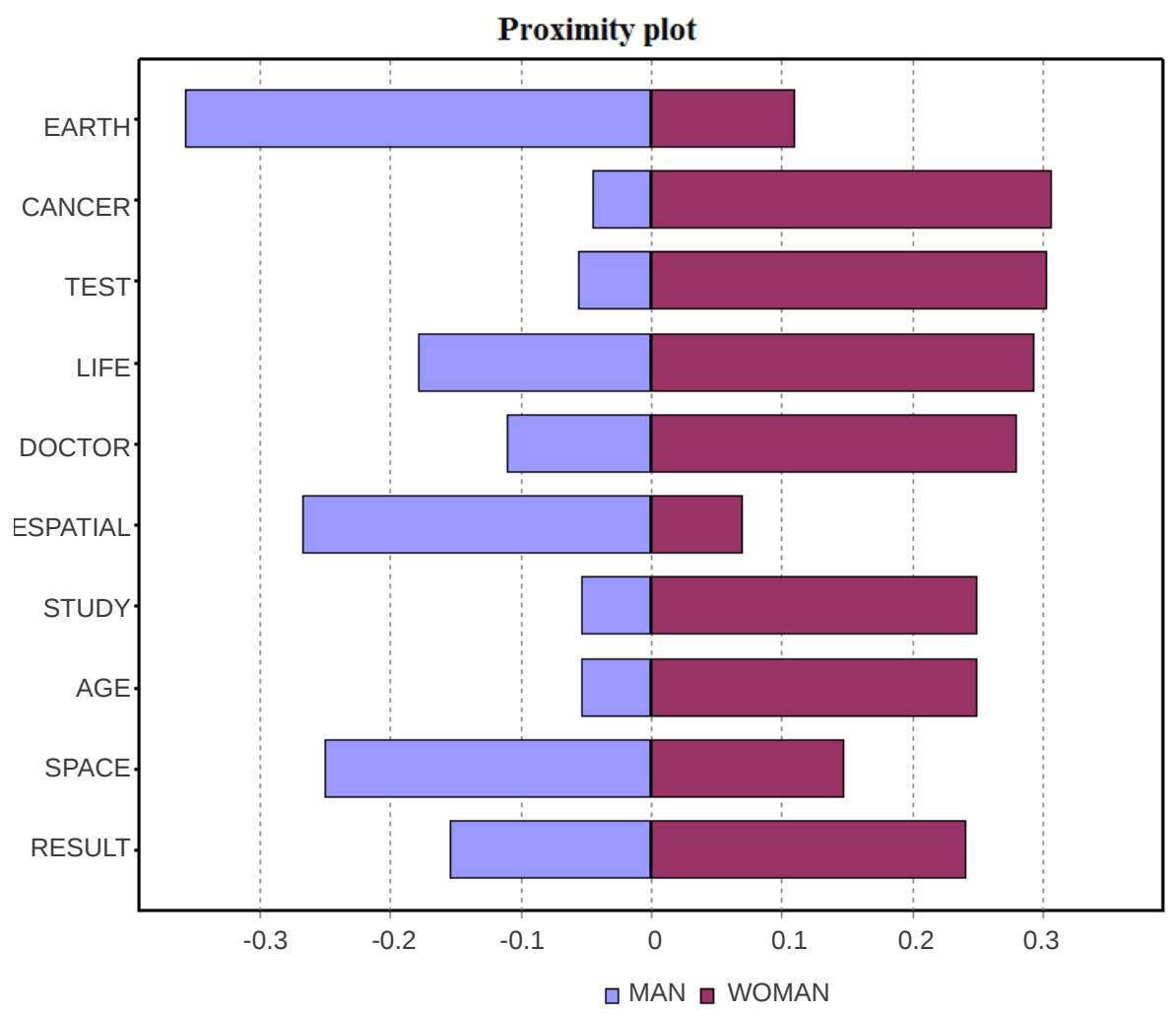

Figure 6. Proximity graph: words most frequently associated with, in the same news report, the term man/men (on the left side of the graph) and the term woman/women (on the right side).

In our constructed week we isolated the excerpts of the news reports in which a female scientist is presented and her speech is reported or broadcast on a video. In our constructed week, the words most often used were "flu", "health" and "female teacher".

In the excerpts that refer to the speech of male scientists the words with most frequent occurrence were "professor", "university", "person", "cancer" and "Brazil". In both cases, the speeches refer to the academic and biomedical environment, which is an obvious consequence of the major importance that the biomedical fields have in science journalism.

Besides identifying the context in which female scientists are interviewed in the news reports, we also investigated all the excerpts - regardless whether they were linked to scientists or not - in which the terms "woman", "man", "men", "human" etc.

The words "woman" and "women" occur often in the news reports (33 times in total, distributed in 18 different texts). In turn, "man" and "men" occur just 22 times in 11 texts. It is interesting to check the connection between these words and the topics they are associated with. We carried out a cluster analysis that allowed us to detect how the most frequently used words in the texts of $J N$ are interconnected. The words "man" and "men" are more likely to appear in texts where there are also words such as "moon", "robots", "astronaut", "Earth", "life", "scientific", etc. (see figure 6). This is certainly 


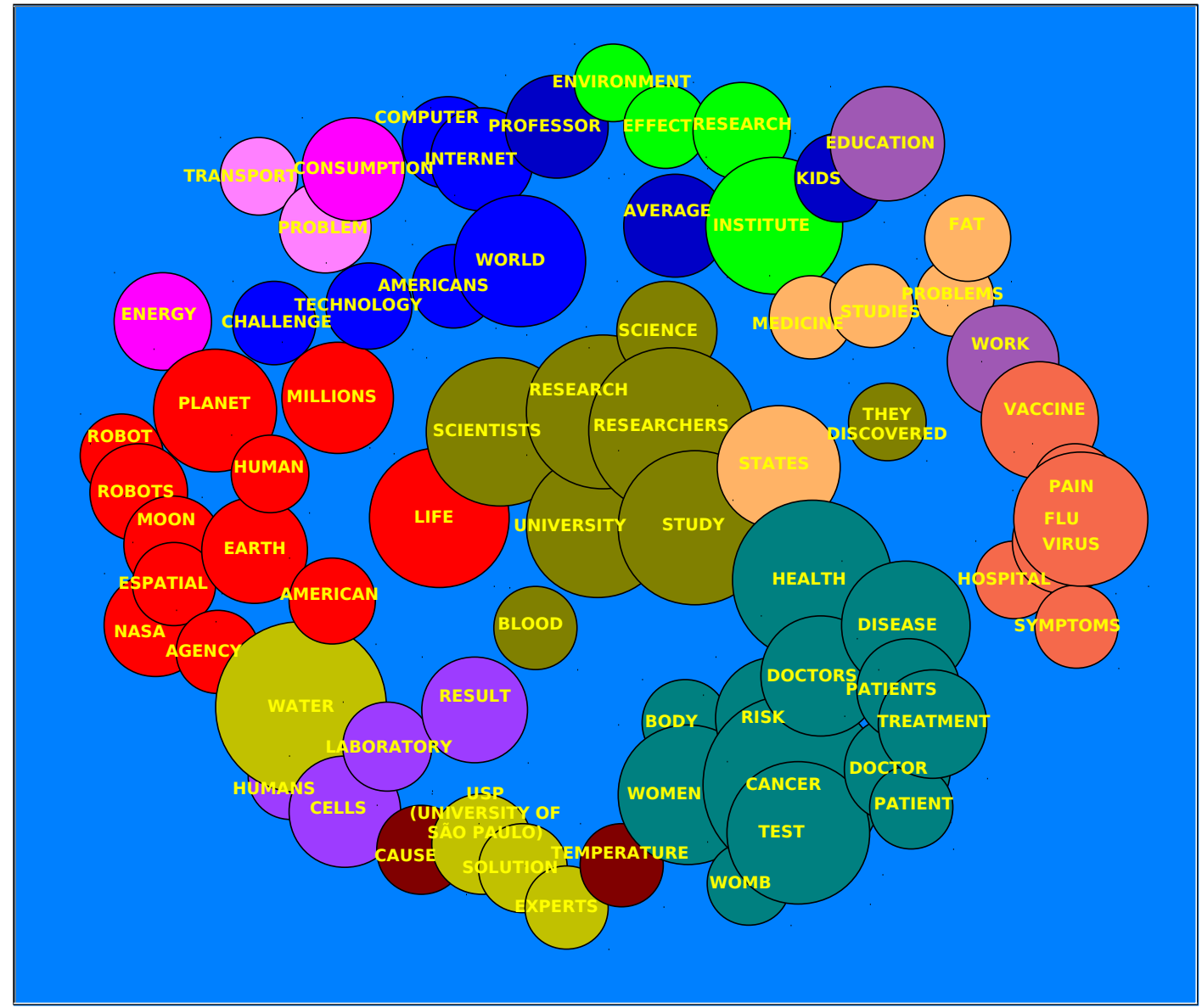

Figure 7. Conceptual map of groups of words often interconnected in the same text. The size of the circles is proportionate to the frequency with which a term is repeated in all the texts.

to be attributed to the fact that in our corpus the story of the "man to the moon" has considerable importance. Similarly, the word "human" tends to be used in texts where the words "robots", "cells", "moon", "science" occur. On the contrary, in our sample, and within the same news report, the terms "woman/women" were more frequently associated with "health", "cancer", "disease", "breast", "mammography", "test", "body", etc. The same result can be visualised through the conceptual map (figure 7).

When the same analysis is carried out searching for associations of words not just in the same text, but that are located in the same paragraph of a text, the result is similar. For example, "women" belongs to the "health" cluster, which is not the same cluster of "researchers" (figure 8). 


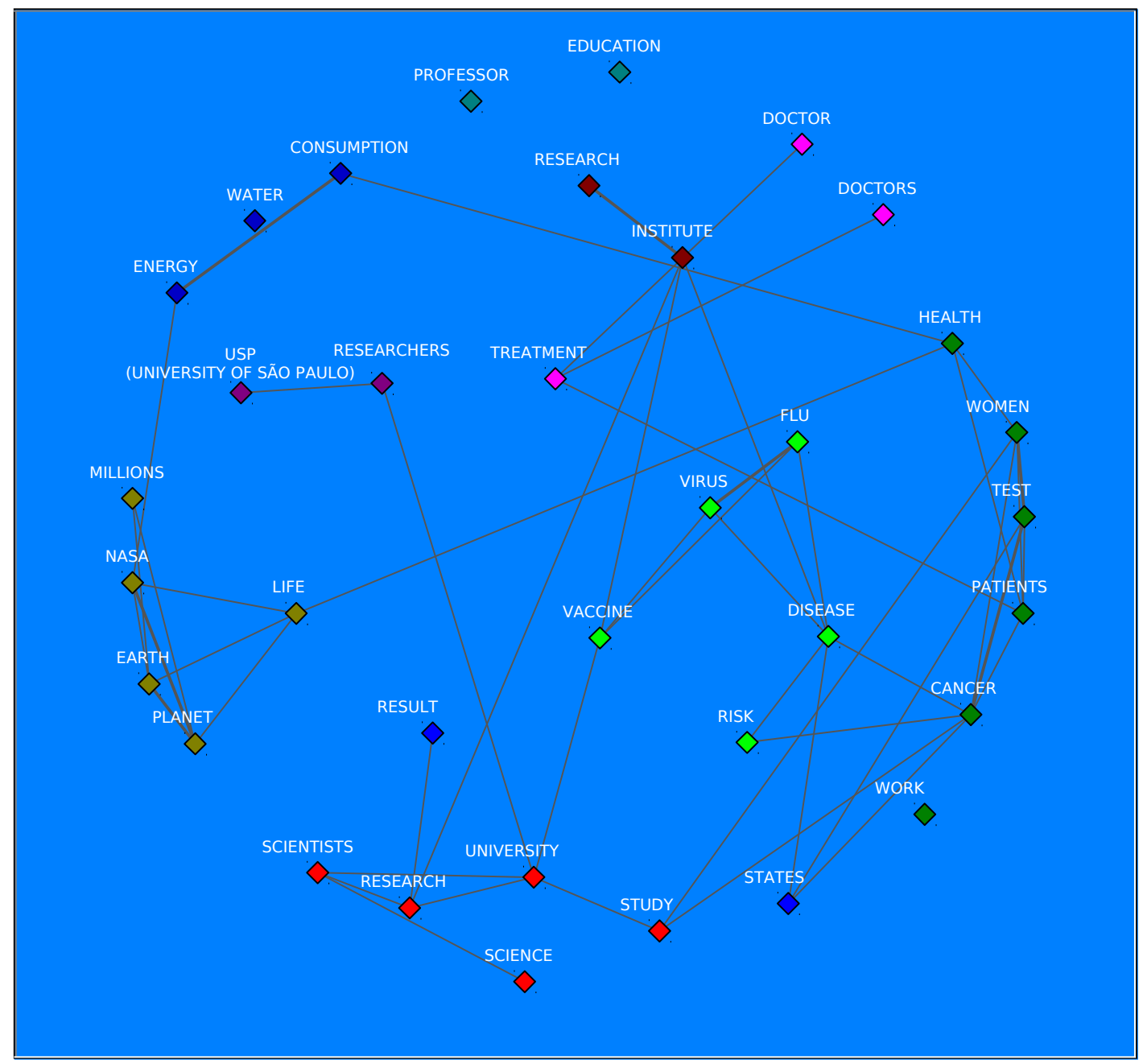

Figure 8. Map of clusters: groups of words which tend to be associated with each other in the same paragraph of a text. The colour of the dots refers to words that belong to the same cluster (i.e. terms that tend to be more frequently located close to each other in the same paragraph of a text).

\section{Final thoughts}

In this work, we analysed the yearly coverage of S\&T issues by the TV news programme with highest audience in Brazil. We noticed the presence of a narrative about S\&T that highlights aspects such as the novelty and the epopee of progress and emphasises reports dedicated to the health and medicine fields, thus corroborating the results observed by Ramalho et al. [11], who also partcipates in our research group.

Yet, the tools used in this study - through the analysis of the transcription of the texts using the QDA Miner software - gave additional and interesting information. The emotional range of nuances was enriched by feelings of fight, anxiety and triumph, visible in the occurrences of terms with semantic connotations of emotional type. The scientific discourse often uses military, sports or competition metaphors. Besides, we observed 
that the scientific debate, although it was hardly dealt with in the sample (just $8 \%$ of the texts), is deeply marked by a critical ethos of distrust, caution, checking, testing and refutation of the hypothesis.

The work carried out by Ramalho et al. [11] identified, through content analysis, a more frequently positive tone in the texts, emphasising the positive aspects of science and a decreased presence of its potential risks. Without jeopardising the significance of the previous study, our work has led to a more detailed observation, identifying not only a general, optimistic discourse about S\&T, but also the nuances and facets of its narrative, which is associated with the idea of innovation and progress, the idea of war (against diseases, social problems, etc.) and the potential controversies or risks of innovation.

In particular, if considered together with the war metaphors, the dimensions which connote emotions related to "triumph" are relevant to the construction of the discourse about S\&T. If S\&T are frequently associated with battles and fights, concerns and dangers, they are also reported as the force that is necessary to successfully win these battles, with metaphors of victory observed in the analysed texts.

Another finding that emerged in our study is the fact that the face presented by the TV news is predominantly masculine. This data is in contrast to the scientific Brazilian community: according to the census conducted by the National Council for Scientific and Technological Development (CNPq) in 2010, the number of female scientists was equal to the number of male scientists in the country [29]. Besides the fact that male scientist appear more frequently in $J N$, the space dedicated to them or their declarations tends to be as double as that dedicated to female scientists.

Furthermore, we also noticed an important distinction between the words related to gender: whereas the terms "man" and "men" have more chances to occur in texts where the words "moon", "robots", "astronaut", "Earth", "life" and "scientific" appear, in the same news report the terms "woman" and "women" were more frequently associated with "health", "cancer", "disease", "breast", "mammography", "test" and "body". These findings suggest a stereotyped role for men and women in society: whereas men go out to literally explore other worlds, women look after their health and body.

This study showed that additional methodological tools give important information that help one deepen the analysis of the representation of science in the media environment. In the next study, it will be important to use these tools to analyse other TV programmes, which we intend to do next.

\section{References}

[1] Ministério da Ciência e Tecnologia, Museu da Vida (2010), Percepção Pública da Ciência e Tecnologia no Brasil, Brasília, Brazil, available at: http://www.museudavida.fiocruz.br/media/enquete2010.pdf.

[2] J.P. Aguirre (2005), La percepción que tienen los colombianos sobre la ciencia y la tecnologíaEncuesta 2004, Colciencias, Bogotá, Colombia.

[3] W. Göpfert (1996), "Scheduled science: TV coverage of science, technology, medicine and social science and programming policies in Britain and Germany", Pub. Underst. Sci. 5(4): 361-374. 
[4] M. Lehmkuh, C. Karamanidou, T. Mörä, K. Petkova and B. Trench (2012), "Scheduling science on television: A comparative analysis of the representations of science in 11 European countries", Pub. Underst. Sci. 21(8): 1002-1018.

[5] B. León (2008), "Science related information in European television: a study of prime-time news", Pub. Underst. Sci. 17(4): 443-460.

[6] A. Hansen and R. Dickinson (1992), "Science coverage in the British mass media: Media output and source input", Communications, 17(3): 365-77.

[7] E. Einsiedel (1992), "Framing science and technology in the Canadian press", Pub. Underst. Sci. 1: 89-103.

[8] M. Bauer, Á. Ragnarsdóttir and A. Rúdólfsdóttir (1993), Science and Technology in the British Press, 1946-1990 - A systematics content analysis of the press, work report, United Kindom.

[9] M.G. Pellechia (1997), "Trends in science coverage: A content analysis of three US newspapers", Pub. Underst. Sci. 6: 49-68.

[10] M. Bucchi and R. Mazzolini (2003), "Big science, little news: science coverage in the Italian daily press, 1946-1997”, Pub. Underst. Sci. 12: 7-24.

[11] M. Ramalho, C. Polino and L. Massarani (2012), "From the laboratory to prime time: science coverage in the main Brazilian TV newscast", J. Sci. Commun. 11: 1.

[12] G. Oliveira (2008), A ciência no Jornal Nacional: entre o fato e a ficção, dissertation (Master), Universidade Federal de Goiás, Faculdade de Artes Visuais, Brasil.

[13] L. Andrade (2004), Iguarias na Hora do Jantar: O espaço da ciência no telejornalismo diário, thesis (doctorate in Education, Management and Dissemination in Science), Universidade Federal do Rio de Janeiro (UFRJ), Rio de Janeiro, Brasil.

[14] M. Ramos (2006), Discursos Sobre Ciência \& Tecnologia no Jornal Nacional, dissertation (Master in Scientific and Technological Education), Universidade Federal de Santa Catarina (UFSC), Florianópolis, Brasil.

[15] A. Alberguini (2007), A Ciência nos Telejornais Brasileiros (O papel educativo e a compreensão pública das matérias de CT\&I), thesis (doctorate in Comunication), Universidade Metodista de São Paulo, São Paulo, Brasil.

[16] Rede Globo (2013), Negócios Globo, Jornal Nacional - Audiência/ Perfil, Rio de Janeiro, available at: http://comercial2.redeglobo.com.br/programacao/Pages/jornal-nacional.aspx\#.

[17] W. Bonner (2009), Jornal Nacional: Modo de fazer, Globo, São Paulo, Brazil, p. 17.

[18] G. Stempel and B. Westley (1989), Research Methods in Mass Communication, Prentice Hall, Englewood Cliffs, NJ, U.S.A. .

[19] K. Krippendorff (1990), Metodología de análisis de contenido. Teoría y Práctica, Ediciones Paidós, Barcelona, Spain.

[20] D. Rondelli (2004), A ciência no picadeiro: Uma análise das reportagens sobre ciência no programa Fantástico, dissertation (Master in Social Comunication), Universidade Metodista de São Paulo, São Paulo, Brasil.

[21] L. Massarani and M. Ramalho (2012), Monitoramento e capacitação em jornalismo científico: a experiência de uma rede ibero-americana, Rio de Janeiro: Museu da Vida, Centro Internacional de Estudios Superiores de Comunicación para América Latina, available at: http://www.museudavida.fiocruz.br/media/monitoramento-e-capacitacao-em-jc.pdf.

[22] M. Nisbet, D. Brossard and A. Kroepsch (2003), "Framing science: the stem cell controversy in a age of pree/politics", Int. J. Press-Polit. 8(2): 36-70.

[23] R.B. Lewis, S.M. Maas (February 2007), “QDA Miner 2.0: Mixed-Model Qualitative Data Analysis Software", Field Methods 19(1): 87-108. 
[24] Y. Castelfranchi (2008), As serpentes e o bastão: tecnociência, neoliberalismo inexorabilidade, thesis (doctorate in Sociology), Universidade Estadual de Campinas, Campinas, Brasil.

[25] D. Nelkin (1995), "Media Messages, Media Effects", in Selling Science: how the press covers science and technology, Freeman and Company, New York, U.S.A. .

[26] N. Péladeau (1998), WordStat Content Analysis Module for SIMSTAT \& QDA Miner: User's Guide, Provalis Research, Montreal, Canada, pp. 22-29.

[27] R. Merton (1973), The Sociology of Science: Theoretical and Empirical Investigations, University of Chicago Press, Chicago, U.S.A. .

[28] N. Péladeau (2004), QDA miner. Qualitative data analysis software user's guide, Provalis Research, Montreal, Canada, p. 128-136.

[29] CNPq (2013), Número de mulheres cientistas já iguala o de homens, available at: http://www.cnpq.br/web/guest/noticiasviews/-/journal_content/56_INSTANCE_a6MO/10157/ 905361.

\section{Authors}

Yurj Castelfranchi graduated as a physicist at University of Rome 1 "La Sapienza" and holds a Master degree in science communication awarded by ISAS (Italy) and a Ph.D. in sociology of S\&T awarded by the State University of Campinas, Unicamp (Brazil). He works as a professor (professor adjunto) of sociology at the Federal University of Minas Gerais (UFMG) and coordinates the interdisciplinary research group InCiTe (Innovation, Citizenship and Technoscience). His main research areas are: techno-scientific citinzenship, social and technical controversies, public perception of S\&T, science and media. E-mail: ycastelfranchi@gmail.com.

Luisa Massarani is a Brazilian journalist who specialised in science in 1987. She holds a Master degree in Information Science (1998) and a PhD in Management, Education and Dissemination of Biosciences awarded by the Federal University of Rio de Janeiro (2001). She collaborates with the Study Group for the Scientific Dissemination at the Life Museum /Oswaldo Cruz Foundation in Rio de Janeiro. She coordinates the section dedicated to Latin American and Caribbean on SciDev.Net (www.scidev.net), which covers news about science and development in developing countries.

E-mail: luisa.massarani3@gmail.com.

Marina Ramalho is a journalist with a degree awarded by the Federal University of Rio de Janeiro (2003) and a PhD in Education, Management and Dissemination of Biosciences awarded by the same university (2013). Since her graduation, she has been working in science journalism. She contributes to the development of products and projects for the scientific dissemination at the Life Museum/Oswaldo Cruz Foundation.

E-mail: marina.fiocruz@gmail.com.

How TO CITE: Y. Castelfranchi, L. Massarani and M. Ramalho, "War, anxiety, optimism and triumph: a study on science in the main Brazilian TV news", JCOM 13(03)(2014)A01. 